www.jmscr.igmpublication.org

Impact Factor (SJIF): 6.379

Index Copernicus Value: 79.54

ISSN (e)-2347-176x ISSN (p) 2455-0450

crossrefDOI: https://dx.doi.org/10.18535/jmscr/v6i11.48

\title{
The Association of Serum Vitamin D and Calcium Levels with Early Recurrent Spontaneous Pregnancy Loss
}

\author{
Authors \\ Prof. Dr Maysoon Shareif, F.I.C.M.S., C.A.B.O.G., A.R.O.C.G ${ }^{1}$. \\ Dr Shaymaa Mahmood K.,M.B.Ch.B. ${ }^{2}$, Dr Nawal Hadi Al-Abassy, M.B.Ch.B. D.O.G. ${ }^{3}$ \\ ${ }^{1,2}$ Department of Gynecology \& Obstetrics, College of Medicine, University of Basrah, Basrah, Iraq \\ ${ }^{3}$ General Health Directorate, Basrah Maternity \& Child Health Hospital, Basrah, Iraq \\ Corresponding Author \\ Prof. Maysoon Sharief \\ Central Post Office-42001, P. O. Box 1565 Ashar, Basrah, Iraq \\ Email: maysoonsharief60@yahoo.com
}

\begin{abstract}
Objective: To study the associated between the serum level of vitamin D and calcium among women with early pregnancy loss.

Study Design: This is a prospective study which is conducted in Basrah Maternity and Child Hospital. The study involved 280 women who were divided into 4 groups: 70 pregnant women with healthy pregnancy in the first group, 70 pregnant women with early unhealthy pregnancy in the second group, further, 70 with non-pregnant women with no pregnancy loss in the third group and then the fourth group included 70 women with non-pregnant women with history of pregnancy loss. Plasma was collected from 280 women and serum 25(OH)D and calcium level were estimated and compared between the groups.

Results: Serum 25(OH)D levels for the 4 groups were measured as $(45.73 \pm 2 \mathrm{ng} / \mathrm{ml})$ in group $1,(20.2 \pm 1.4$ $\mathrm{ng} / \mathrm{ml})$ in group 2, $(37.6 \pm 2.1 \mathrm{ng} / \mathrm{ml})$ in group 3 and $(11.5 \pm 3.1 \mathrm{ng} / \mathrm{ml})$ in group 4. There was a clear correlation between low 25(OH)D levels as well as low calcium level and early pregnancy loss.

Conclusion: Vitamin $D$ has a significant role during pregnancy from early implantation and decidualization phase till late pregnancy. Vitamin D deficiency related to poor obstetric outcome. Many studies proved that Vitamin D supplement improved outcome. So, routine screening and supplementation of vitamin $D$ in early pregnancy especially during first trimester are recommended.

Keywords: Calcium, Miscarriage, Pregnancy, Vitamin D.
\end{abstract}

\section{Introduction}

Recurrent spontaneous miscarriage (RSM) refers to circumstances where two or more consecutive clinical pregnancies fail before 20 weeks of gestation $^{1}$. RSM is a common negative pregnancy outcome that occurs in women worldwide. Causes of RSM are related to genetic factors, anatomical abnormalities, infections, and endocrine disorders 2 . However, the causes of the majority of RSM cases are unknown, and may be related to autoimmunity ${ }^{3}$.

Vitamin D is a secosteroid hormone that plays a vital role in bone metabolism and mineral homeostasis ${ }^{4}$. In addition, vitamin D modulates 
the immune system $^{5}$. Thus, its deficiency/insufficiency could increase the risk of many chronic diseases involving immunological dysfunction $^{6}$. The human reproductive process is also regulated by the immune system. Vitamin D has been associated with infertility, polycystic ovary syndrome, in vitro fertilization outcomes ${ }^{7}$, obstetrical outcomes ${ }^{8}$, and male gonadal function ${ }^{9}$. During pregnancy, low vitamin D status may increase the risk of obstetrical complications ${ }^{10}$. A high proportion of RSM patients reportedly have vitamin D deficiency ${ }^{11}$, and low concentrations of vitamin $\mathrm{D}$ have been associated with an increased risk of first trimester miscarriage ${ }^{12}$.

However, the exact effects of vitamin $\mathrm{D}$ on pregnancy outcome remain unclear. Normal pregnancies depend on synchronized immuneendocrine crosstalk at the maternal-fetal interface 13

Vitamin D deficiency is a common problem in reproductive aged women in industrialized countries and its prevalence may be increasing ${ }^{14}$. The etiology for this increase is likely multifactorial, but due in part to low dietary intake of vitamin D and limited exposure to sunlight. Certain high risk groups for vitamin D deficiency in pregnancy have been identified, including vegetarians, women with limited sun exposure (e.g., those who live in cold climates, northern latitudes, or wear sun and winter protective clothing), and ethnic minorities, especially those with darker skin ${ }^{15}$. Vitamin D deficiency is also more common among heavier women than leaner individuals $^{16}$. Therefore, the aim of the study is to investigate the serum levels of vitamin $\mathrm{D}$ and calcium among women with early recurrent pregnancy loss.

\section{Patients and Methods}

A prospective study was conducted at Basrah Maternity and Child Hospital during the period between 1st of January 2016 till the 1st of April 2018. Written consent was obtained from all the women involved in the study. The age of women involved in the study ranged between 16-35 years with a mean of $28.5 \pm 2.0$. All the cases were collected from antenatal clinic of the Maternity Hospital and private clinics.

1st group $(\mathrm{N}=70)$ consisted of women with viable pregnancy at gestational age between 8-10 weeks, who were followed till the 3rd trimester.

2nd group $(\mathrm{N}=70)$ consisted of pregnant women with unhealthy pregnancy and vaginal bleeding before 10 weeks.

3rd group $(\mathrm{N}=70)$ consisted of non-pregnant women with previous history of normal healthy pregnancy.

4th $(\mathrm{N}=70)$ included non-pregnant women with previous history of miscarriage.

Exclusion criteria were all women with a known metabolic disease like thyroid disorder, diabetes mellitus, women with uterine malformations, positive serological test of TORCH, history of positive chromosomal abnormalities, users of vitamin D supplements.

All the clinical parameters were recorded regard maternal age, body mass index (BMI), parity, socio economic status and the gestational age at the time of the study which assessed by the date of the last menstrual period and early ultrasound examination .

The socioeconomic data on per capita monthly family income in Iraqi dinars (IQD) which was classified as low (80-100,000 IQD), medium $(100,000-200,000 \mathrm{IQD})$ and high $\sim(200,000) .{ }^{17}$

Maternal blood was collected and plasma was separated by centrifugation at $1500 \mathrm{xg}$ at $4^{\circ} \mathrm{C}$ in RC3 centrifuge. Samples were a liquated into multiple tubes and stored at $-14^{\circ} \mathrm{C}$. Total $25-\mathrm{OH}$ vitamin $\mathrm{D}$ concentration $(\mathrm{ng} / \mathrm{ml})$ were measured in patient's plasma samples by using high performance liquid chromatography (HPLC) .

Recently published criteria from the institute of medicine were used to categorize vitamin D status by plasma $25(\mathrm{OH}) \mathrm{D}$ concentration as ${ }^{18}$ :-

1) Severe deficiency $<10 \mathrm{ng} / \mathrm{ml}(25 \mathrm{nmol} / \mathrm{L})$.

2) Deficency $<20 \mathrm{ng} / \mathrm{ml}(50 \mathrm{nmol} / \mathrm{L})$.

3) Insuffiency $\left(\begin{array}{llllll}21 & -29 & \mathrm{ng} / & \mathrm{ml} & (51 & -74\end{array}\right.$ $\mathrm{nmol} / \mathrm{L})$.

4) 4 Sufficiency $>30 \mathrm{ng} / \mathrm{ml}(75 \mathrm{nmol} / \mathrm{L})$ 
Statistical analysis: The data were analyzed using statistical package social science (SPSS). The descriptive statistics were expressed as standard deviation and mean. $\mathrm{p}$ value $<0.05$ was considered statistically significant.

\section{Results}

A total of 280 women were included in the study, the age was ranging between 18-35years, with mean age of $28.5 \pm 2$. Out of 280 women, 140 of them had early pregnancy, which included 70 women with early viable pregnancy at 8-10 weeks and 70 women with unhealthy pregnancy before
10 weeks. There were 140 non pregnant women, 70 out of them had history of previous normal pregnancy and the remaining 70 are non-pregnant women who had history of previous more than one miscarriage.

Table 1 showed the comparison of the demographic and clinical data of all groups. It was showed that there is no statistical difference between the all groups regarding the age, BMI and social class. $\mathrm{P}>0.05$ hence there is no significant difference between the early pregnancy groups regarding the gestational age with the mean gestational age of both groups is $8.5 \pm 3$.

Table 1 Demographics and clinical data of the studied groups

\begin{tabular}{|c|c|c|c|c|c|}
\hline & $\begin{array}{c}\text { Group } 1 \\
(\mathrm{~N}=70) \\
\text { mean }\end{array}$ & $\begin{array}{c}\text { Group } 2 \\
(\mathrm{~N}=70) \\
\text { mean }\end{array}$ & $\begin{array}{c}\text { Group } 3 \\
(\mathrm{~N}=70) \\
\text { mean }\end{array}$ & $\begin{array}{c}\text { Group4 } \\
(\mathrm{N}=70) \\
\text { mean }\end{array}$ & $\mathrm{P}$ value \\
\hline Age (years) & $27 \pm 1.5$ & $28.2 \pm 2.1$ & $29 \pm 1.1$ & $27.9 \pm 2.1$ & NS \\
\hline BMI Kg/m2 & $21.8 \pm 1.2$ & $22.8 \pm 2.5$ & $23.1 \pm 1.5$ & $22.5 \pm 3.3$ & NS \\
\hline \multicolumn{6}{|l|}{ Socioeconomic status } \\
\hline Low & 25 & 23 & 28 & 26 & NS \\
\hline Medium & 34 & 31 & 29 & 30 & NS \\
\hline High & 11 & 16 & 13 & 14 & NS \\
\hline Parity & $3 \pm 1.5$ & $1.5 \pm 2.5$ & $4 \pm 2.5$ & $1.3 \pm 1.2$ & NS \\
\hline Gestational age (weeks) & $8 \pm 3$ & $9 \pm 2$ & & & NS \\
\hline
\end{tabular}

Table 2 showed a comparison of laboratory data for the groups.

The serum 25(OH/D) levels for group one (healthy pregnancy) was $45.73 \pm 2$, group 2 (unhealthy pregnancy) was $26.2 \pm 1.4$, for group 3 was $37.6 \pm 2.1$ and group 4 was $11.5 \pm 3.1$. The highest concentration in group of healthy pregnancy and the lowest level is in group 4 (nonpregnant with recurrent pregnancy loss). There was a statistically significant difference between serum $25(\mathrm{OH} / \mathrm{D})$ levels in the 1 st and 2 nd group and between 3rd and 4th. Calcium levels were found lower in group 2 than group 1,3 and 4

Table 2 The value of the laboratory data among the studied groups

\begin{tabular}{|l|c|c|c|c|c|}
\hline & Group1 & Group2 & Group3 & Group4 & P value \\
\hline $\begin{array}{l}25-\mathrm{OH} \\
\mathrm{D} \text { ng/ml }\end{array}$ & $45.73 \pm 2^{\mathrm{a}}$ & $20 \pm 1.4$ & $37 \pm 2.1$ & $11.51 \pm 3^{\mathrm{b}}$ & $\mathrm{S}$ \\
\hline Ca+mg/dl & $11 \pm 0.14^{\mathrm{c}}$ & $7.6 \pm 0.12^{\mathrm{d}}$ & $9.7+0.16$ & $7.7 \pm 0.2$ & $\mathrm{~S}$ \\
\hline
\end{tabular}

a- significantly higher than group 2 , group 3 and group $4(0.001,0.003,0.001)$ respectively.

b-significantly lower when compared to group 2 and group $3(0.001,0.002)$ respectively.

c-significantly higher when compared to group 2 and 4 (0.005).

d-significantly lower when compared to group 2 and 3 .

\section{Discussion}

The relationship of vitamin D on skeletal system and calcium metabolism are well understood. While it's effected on cardiovascular system, immune system and reproductive system are not well improved.
There is a great relationship between immunity system and vitamin $\mathrm{D}^{19}$. It was found that $\mathrm{T}$ cell, $\mathrm{B}$ cell have vitamin $\mathrm{D}$ receptor and can produce 1,25 , di-hydroxy V.D the active form of vitamin D 20 . 
There should be a balance between Th1,Th2 in the immune system, it was approved that 1,25, dihydroxy vitamin D is an inhibitor of Th1 cell proliferation, and cytokines, it activates and regulates Th2 cells and its function ${ }^{21}$.

In pregnancy there is a proper regulation of hostantigen relation between the pregnant women and the fetus, beside there is suppression of mother immunity except dominate humeral immunity during healthy pregnancy. Therefore cellular immunity which is suppressed in form of suppression of Th1 and natural killer (NK) cells and change in the Th1/Th2 balance which prevent pregnancy rejection, beside that it was observed that over expression of Th1 cytokines may lead to miscarrage ${ }^{22}$.

Vitamin D deficiency lead to high level of natural killer cells during pregnancy and according to this fact vitamin D could act as an immune regulator during implantation and play an important role in regulation of reproductive function ${ }^{22}$.

Barrera et al. showed that Th1 and NK cells level increase in women with un explained recurrent miscarriage and multiple implantation failure after in vitro fertilization and this study demonstrated that vitamin D triggers local anti-inflammatory response and induce decasualization for pregnancy $^{23}$.

This prospective study analyzed the association between $25(\mathrm{OH}) \mathrm{D}$ concentration and subsequent risk of miscarriage. There is significant high serum level of vitamin D in the normal pregnancy in comparing with unhealthy pregnancy. This finding is in agreement with the other studies ${ }^{24,25}$, who demonstrated that low serum level of 25 $(\mathrm{OH})$ D were associated with increased risk of miscarriage in the first trimester. This can be due to anti-inflammatory effect of vitamin D. One study found low maternal serum vitamin D and also its low levels in chorionic villi and decidua during pregnancy ${ }^{26}$.

In this study serum level of vitamin D is higher in non- pregnant women with no history of pregnancy loss in comparing with non- pregnant women with previous miscarriage.
It was observed in some studies which was done among women of childbearing age with history of pregnancy loss, that $86 \%$ of women with one or more pregnancy loss in the first trimester were associated with vitamin D deficiency, and with history of $96 \%$ of non graved childbearing age women reported having sufficient serum $25(\mathrm{OH}) \mathrm{D}$ more than (30ng/L) successful pregnancies ${ }^{27,} 28$. Some studies observed great relationship between vitamin D and Autoantibody. that low serum level of vitamin D appears to be associated with auto immune disease severity and susceptibility due to increased presence of auto antibodies via B cell hyper activation and auto antibody production ${ }^{29}$, 30

It is also observed that vitamin $\mathrm{D}$ has been demonstrated to inhibit secretion of proinflammatory cytokines such as TNF alpha,IL-6 and interferon $\mathrm{B}$ in the placenta.1,25, $(\mathrm{OH}) 2 \mathrm{D}$ concentration are dependent on the availability of $25(\mathrm{OH}) \mathrm{D}$ and the converting enzyme CYP27B11 30

I this study unhealthy pregnant women had lower calcium levels than women in normal pregnancy group Which is related to metabolic and hormonal dysfunctions in women with miscarriage ${ }^{31,32}$. Previous study observed that the healthy women in the childbearing age, the serum level of vitamin $\mathrm{D}$ is higher than the women suffering from polycystic ovaries syndrome and they found that $68 \%$ of polycystic ovaries women had vitamin D deficiency which lead to early pregnancy loss once women with polycystic ovaries syndrome conceived $^{32}$.

In conclusion, vitamin $\mathrm{D}$ has a significant role during pregnancy started from early implantation and decidulization phase till late pregnancy. Vitamin D deficiency is related to poor obstetric outcomes.

Therefore, child bearing aged women with the failed pregnancies better to be screened for their vitamin D levels among pre-conception counseling and its possible to recommend routine supplementation of vitamin D in early pregnancy especially in pregnancy with first trimester loss. 


\section{References}

1. Comba C, Bastu E, Dural O, Yasa C, Keskin G, Ozsurmeli M, et al. Role of inflammatory mediators in patients with recurrent pregnancy loss. Fertil Steril. 2015; 104: 1467-1474.

2. Abdi-Shayan S, Monfaredan A, Moradi Z, Oskoui MR, Kazemi T. Association of CD46 IVS1-1724 C>G single nucleotide polymorphism in Iranian women with unexplained recurrent spontaneous abortion (URSM ) Iran J Allergy Asthma Immunol. 2016;15:303-308.

3. Lee SK, Kim JY, Lee M, Gilman-Sachs A, Kwak-Kim J. Th17 and regulatory T cells in women with recurrent pregnancy loss. Am J Reprod Immunol. 2012; 67: 311318.

4. Tamblyn JA, Hewison M, Wagner CL, Bulmer JN, Kilby MD. Immunological role of vitamin $\mathrm{D}$ at the maternal-fetal interface. J Endocrinol. 2015; 224: 107121.

5. Lagishetty $\mathrm{V}$, Liu NQ, Hewison $\mathrm{M}$. Vitamin D metabolism and innate immunity. Mol Cell Endocrinol. 2011; 347: 97-105.

6. Holick MF. The vitamin D deficiency pandemic: a forgotten hormone important for health. Public Health Reviews 2006; 32(1): 267-283.

7. Shahrokhi SZ, Ghaffari F, Kazerouni F. Role of vitamin D in female reproduction. Clin Chem Acta. 2015; 455: 33-38.

8. Franasiak JM. Vitamin D in human reproduction-an evolving landscape.Fertil Steril. 2016; 106: 1650-1651.

9. Karras S, Anagnostis P, Kotsa K, Goulis DG. Vitamin D and gonadal function in men: a potential inverse U-shaped association? Andrology. 2016; 4: 542-544.

10. Urrutia RP, Thorp JM. Vitamin D in pregnancy: current concepts. Curr Opin Obstet Gynecol. 2012; 24: 57-64.
11. Ota K, Dambaeva S, Han AR, Beaman K, Gilman-Sachs A, Kwak-Kim J. Vitamin D deficiency may be a risk factor for recurrent pregnancy losses by increasing cellular immunity and autoimmunity. Hum Reprod. 2014; 29: 208-211.

12. Andersen LB, Jørgensen JS, Jensen TK, Dalgård $\mathrm{C}$, Barington $\mathrm{T}$, Nielsen $\mathrm{J}$, et al. Vitamin D insufficiency is associated with increased risk of first-trimester miscarriage in the Odense Child Cohort. Am J Clin Nutr. 2015; 102: 633-638.

13. Nair RR, Verma P, Singh K. Immuneendocrine crosstalk during pregnancy. Gen Comp Endocrinol. 2016; 242: 18-23.

14. Looker AC, Pfeiffer CM, Lacher DA, Schleicher RL, Picciano MF, Yetley EA. Serum 25-hydroxyvitamin D status of the US population: 1988-1994 compared with 2000-2004. Am J Clin Nutr 2008; 88(6): 1519-1527.

15. American College of Obstetrics and Gynecology. ACOG committee: Opinion number 495: Vitamin D: screening and supplementation during pregnancy. Obstet Gynecol 2011; 118(1): 197-198.

16. Yetley EA. Assessing the vitamin D status of the US population. Am J Clin Nutr 2008; 88(2): 558S-564S.

17. RAND corporation . Medical outcome study 36- Item short form survey instrument (51-36).Santa Monica , California RAND Health 2009.

18. Ross AC, Taylor CI, Yaktine AL, Dcl Valle HB. Dietary Reference Intakes for Calcium and Vitamin D 2011-08-06 ed: National Academic press 1451; 2011.

19. Hou W, Yan XT, Bai PM, Zhang XW, Yu $X W$. Decreased serum vitamin D levels in early spontaneous pregnancy loss. Eur J clin Nutr. 2016 ; 70 (9): 1004-1008.

20. Adorini L, Penna G. Control of autoimmune disease by the vitamin D endocrine system. Nat Clin. Pract Rheumatol. 2008 ; 4(8): 404- 412. 
21. Lemire JM, Adams JS, Sakai R, Jordans SC. 1 Alpha 25 dihydroxy vitamin D3 suppression proliferation and immunoglobulin production by normal human peripheral blood mononuclear cells J Clin. Invest. 1984; 74(2): 657-661.

22. Szekeres-Bartho J . Immunological relationship between the mother and the fetus. Intern Rev immunol. 2002; 21(6): 471-495.

23. Barrera D, Avila E, Hernandez G, et al. Estradiol and progesterone synthesis in human placenta is stimulated by calcitroil . J Steroid Biochemic Mol Boil 2007; 103 (3-5): 529- 530.

24. Loiuse B, Andersen, Jan s Jorgensen, K Jensen, et al. Vitamin D insufficiency is associated with increased risk of first trimester miscarriage in the odase child cohort Am J Clin Nutr 2015; 102: 623681.

25. Lehriz HA, Yeliz A, Oktay O. Is there an association between early pregnancy loss and low 25. Hydroxy vitamin D level? POJ Gynecology and Obstetric Research www.proscolar.org.

26. Wong LQ, Yan CF. Women with recurrent miscarriage have decreased expression of 25-hydroxy vitamin D3-1 alfa-Hydoxylase by the fetal maternal interface. PLOS one 2016 ; 11 (12).

27. Ota K, Dambaeva S, Han AR, Beaman K, Gilman-sachs A, Kmak-kim J. Vitamin D deficiency may be a risk factor for recurrent pregnancy loss by increasing cellular immunity and autoimmunity. Hum Reprod. 2014; 24 (2): 208 -219.

28. Hou W, Yan XT, Bai C-m, Zhang XW, Hui L-Y, Wyu X. Decreased serum vitamin $\mathrm{D}$ levels in early spontaneous pregnancy loss. European J Clin Nutrition 2016; 70: 1004-1008.

29. Ritterhouse LL . Crowe SR, Niewold TB, Kamen DL, et al .Vitamin D deficiency is associated with an increase autoimmune response in healthy individuals and in patients with systemic lupus erythematosus. Ann Rheam Dis 2011; 70: v1569-1579.

30. Dfaz L ,Noyola- Martinez N , Barrera D , et al. TNF- alph - induced inflammatory cytokines in human trophoblasts. J Reprod immunol 2009; 81: $17-24$.

31. Hollis BW, Wagner CL. New insights into the vitamin $\mathrm{D}$ requirements during pregnancy. Bone Research 2017; 5: 1-16.

32. He C , Linz A, Robb SW, Ezeamanna AE. Serum vitamin D levels and polycystic ovary syndrome : a systemic review and meta-analysis Nutrients 2015 ; 7: 45554577. 